\title{
FOOD IN A NEST WHERE FEMALE GREAT HORNED OWL DIED
}

DAN ZAZELENCHUK, email: danzaz@sasktel.net

The female great horned owl (Bubo virginianus) was electrocuted 6 May, 2014. This was the food the male had brought up to 18 May, 2014: 6 rock pigeons, 4 Nuttall's cottontails, a blackbilled magpie, a Richardson's ground squirrel and a sora rail.

Fortunately, he must have brought smaller prey as well - voles, mice - because the two young were healthy. But, they must have been hungry and begging quite a bit, because he kept bringing food, a lot of it too big for them to eat. Some of it was getting a little ripe.

More support for the hypothesis that the male isn't programmed to feed the young, just bring the food. As well as a good hunter, the male was protective too. He got a good shot in on Martin while Martin was up the tree, and he made many passes during the banding. Often the male is the shy one, leaving the attacks to the female.

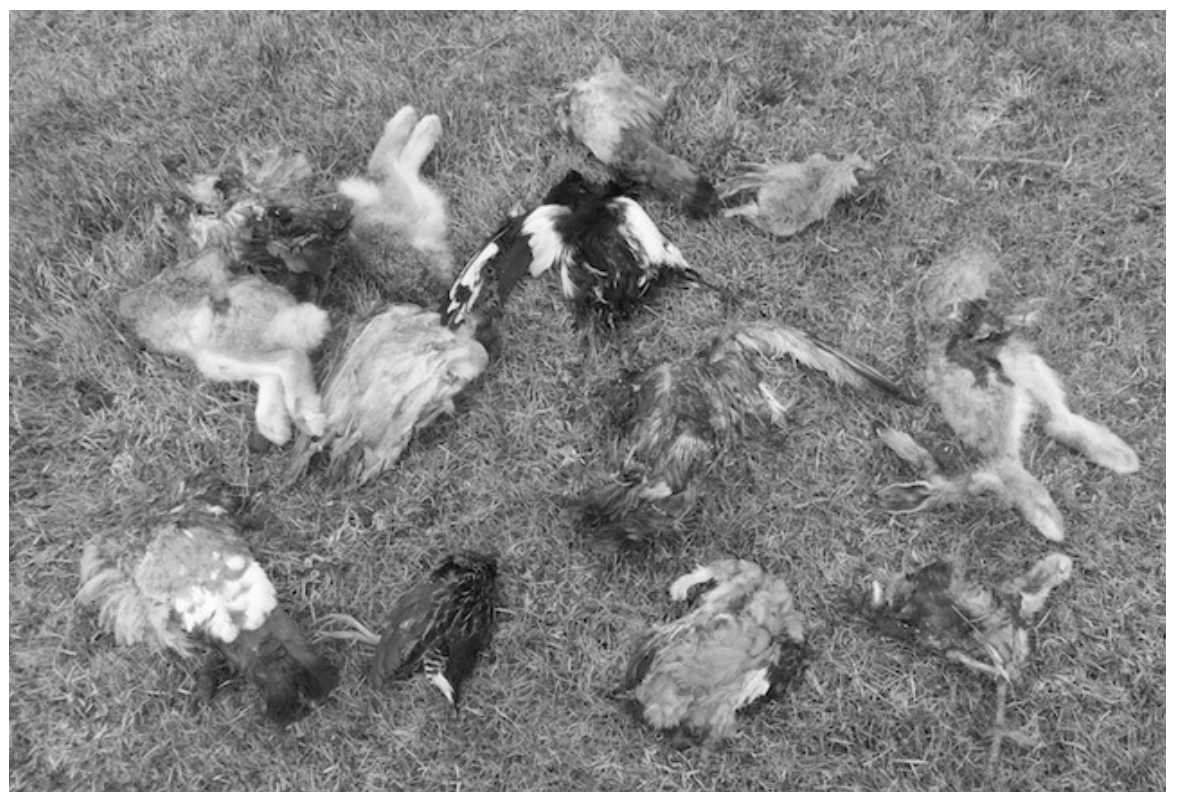

Food items from nest 


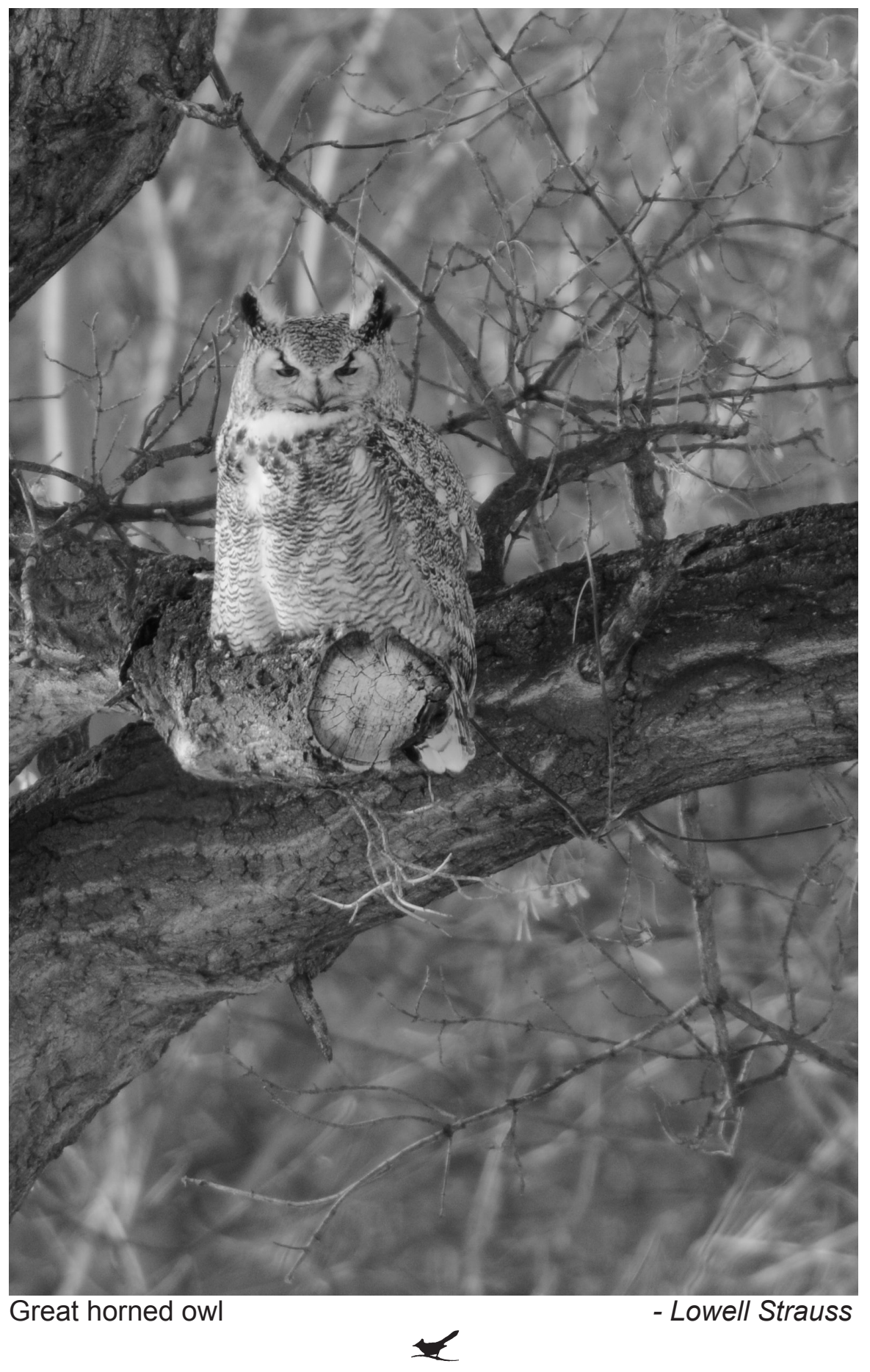

72 (4) December 2014 